\title{
Origin of volcanic rocks in Japanese island arcs
}

Studies on volcanic rocks commenced in Japan more than 100 years ago as petrographic work on the volcanic rocks of the Japanese islands. These studies applied the microscopic methods developed in Europe and were extended later to include studies on the origin of volcanic rocks. The researchers were affected significantly by the experimental and theoretical work that developed in the United States in the early 20 th century. Since the 1930s, original contributions have been made by Japanese petrologists on the origin of volcanic rocks. Later petrological, volcanological, geophysical, and geochemical work on volcanic rocks has been concerned with the source and mechanisms of the generation and ascent of magmas in subduction zones.

\section{History of petrology on volcanic rocks in Japan}

This review article consists of two parts. The first part presents a brief review of the history of igneous petrology in Japan, particularly that concerned with volcanic rocks, and the second part gives a summary of recent studies on the origin of magmas in Japanese island arcs. However, this short article cannot cover all the relevant studies, so some selection of studies must be made, and although the author has tried to be equitable, the selection may be biased by the author's preferences, prejudices, and familiarities.

\section{Initiation and progress of igneous petrology}

Petrology in Japan was initiated in the late 19th century by the introduction of petrography that was developed in Germany. Bunjiro Koto, who graduated from the University of Tokyo in 1879 as one of its first graduates, was sent to Germany by the Japanese Government and learned petrography from 1880 to 1884 under F. Zirkel of the University of Leipzich. During his stay in Germany, he published a paper on igneous rocks in the Kanto region, central Japan (Koto, 1884), which was the first professional petrographic paper written by a Japanese scientist. After he returned to Japan, he held a chair of petrology for 36 years at the Geological Institute of the University of Tokyo and introduced the modern petrographic method to Japan. He conducted petrographic studies of igneous and metamorphic rocks, and his later work was extended to structural geology, volcanoes, and earthquakes in Japan. Koto (1916) published a series of papers concerning volcanoes and volcanic rocks, in which he defined volcanic zones in the Japanese islands, distinguished differences in the petrographic character of volcanic rocks, particularly andesite, between northeastern and southwestern Japan, and proposed a petrographic province in the central zone in southwestern Japan. Petro- graphic studies on igneous rocks in Japan were made also by Koto's students, most of whom were influenced by J.P. Iddings, A. Harker, and F. Becke.

The period of modern igneous petrology started in Japan in the early 20th century. In 1912, the Department of Geology was established in Tohoku University, where S. Kozu initiated, with M. Oba, a petrologic study of igneous rocks that was based on physicochemical principles. Kozu also was influenced by Iddings, Harker, and Becke, but he was stimulated most by the physico-chemical studies that were being carried out at the Geophysical Laboratory of the Carnegie Institution of Washington, D.C., USA, which was established in 1907, and Kozu and his colleagues attempted hightemperature melting experiments on igneous rocks. Later, Kozu even measured the viscosity of silicate melts of geological interest with $\mathrm{K}$. Kani (Kani, 1934; Kozu and Kani, 1935). Their studies were, however, too modern at that time in Japan and did not become popular among Japanese geologists.

Modern igneous petrology was initiated also at the University of Tokyo when S. Tsuboi succeeded B. Koto in 1923 and held a chair of petrology at the Geological Institute of the University of Tokyo. From 1921 to 1923 , he visited major universities and institutions in Europe and the United States. During his stay in the United States, he was impressed particularly by the work of N.L. Bowen at the Geophysical Laboratory, and his subsequent work on igneous rocks was affected strongly by Bowen's philosophy and work. After Tsuboi returned to Japan, he established the method of optical mineralogy in Japan and applied it to a number of igneous and metamorphic rocks in the Japanese islands and adjacent areas. He developed a new method for determining the composition of plagioclase feldspar by using the refractive indices of cleavage flakes (Tsuboi, 1923). At the same time, he investigated the origin of igneous rocks on the basis of the concept of the reaction principle and fractional crystallization advocated by Bowen. His work on the crystallization of pyroxenes from magma was original and outstanding at that time (Tsuboi, 1932), and Tsuboi's petrologic studies were of high quality even by international standards. Through these studies, Tsuboi raised the level of petrology in Japan and stimulated and educated many students.

Tsuboi's work on volcanic rocks was continued by several of his students. Tomita (1935) studied volcanic rocks surrounding the Sea of Japan and proposed an alkali rock province around the Sea of Japan. He investigated the relationship between the tholeiitic basalt magma type and the alkali olivine basalt magma type distinguished by Kennedy (1933) and concluded that the alkali olivine basait magma type was formed by the assimilation of granitic rocks by the tholeiitic basalt magma type. Kennedy and Anderson (1938) aiso postulated the same genetic relationship between the two magma types. The role of assimilation of granitic rocks by basaltic magma became fashionable at the time. K. Sugi, whose major work was on metamorphic rocks, studied sanukitoid rocks in the northern part of the island of Shikoku, and he proposed that these sanukitoid rocks were formed by the assimilation of granitic rocks and aluminous metamorphic rocks by basaltic magma (Sugi, 1938). He also studied basaltic rocks in the San-in district of Honshu and in northern Kyushu, southwestern Japan, and he came to the same conclusion reached by Tomita and by Kennedy and Anderson (Sugi, 1942). 


\section{Intensive studies in volcanic petrology}

Petrologic studies of volcanic rocks in Japan became intensive in the 1930s. H. Tsuya, who was one of Tsuboi's students, studied Fuji volcano in great detail as his lifetime work. He also examined volcanic rocks in the Fuji volcanic zone and distinguished the petrographic characteristics between the northern and southern parts. For example, basalts in the northern part are systematically higher in alkalis and lower in silica than those in the southern part (Tsuya, 1937, 1940).

Among Tsuboi's students, H. Kuno carried out the most influential studies on the genesis of island arc volcanic rocks. He started his work on volcanic rocks in northern Izu peninsula of south-central Honshu, and he followed this by work on Hakone volcano in southeastern Honshu, which he devoted himself to study. In his extensive and detailed studies on Hakone volcano, Kuno distinguished two volcanic rock series, the pigeonitic rock series and the hypersthenic rock series, that were based on the groundmass pyroxenes (Kuno, 1950). He considered the hypersthenic rock series, which corresponds approximately to the calc-alkalic rock series, to have formed by the assimilation of granitic materials by basaltic magma of the pigeonitic rock series, which corresponds to the tholeitic rock series. Nearly at the same time, Tilley (1950) independently reached the same conclusion. Kuno emphasized fractional crystallization of basalt magma as being most important for the origin of volcanic rocks of both series, including andesite of the calc-alkalic or hypersthenic rock series. Later, Kuno's work was extended to include volcanic rocks in all the Japanese islands. He distinguished the zones of tholeite and alkali basalt that extend along the Japanese island arcs and are nearly parallel to the trench in the northeastern Japan arc (Kuno, 1959). Further, he later recognized the zone of high-alumina basalt that lies between these two basalt zones (Kuno, 1960). Kuno also studied basalts in the Hawaiian Islands and proposed an original idea that alkali basalt magma is formed at deeper levels and higher pressures than tholeiitic basalt magma by partial melting in the upper mantle (Kuno and others, 1957). In the Japanese island arcs, he considered the deep seismic zone (Wadati-Benioff zone) to be the site of generation of basalt magma. This means that the depth of generation of basalt magma becomes deeper going from the trench side of the islands toward the Sea of Japan side, which thus explains the zonal distribution of tholeiite, high-alumina basalt, and alkali basalt across the Japanese island arcs (Kuno, 1959). Later, Kuno studied upper mantle xenoliths at Ichinomegata in northeastern Japan and in Hawail in relation to the source materials of basalt magmas (Kuno, 1967; Kuno and Aoki, 1970). Most of Kuno's studies stimulated subsequent experimental studies, which flourished in the 1960s.

Kuno's petrologic work on volcanic rocks was extended subsequently by several of his colleagues and students at the University of Tokyo. Among them, M. Yamasaki, N. Isshiki, and S. Aramaki made notable petrologic studies of volcanic rocks, as well as volcanological studies on Quaternary volcanoes in Japan. Yamasaki studied Nikko, Tateyama, and Hakusan volcanoes (for example, see Yamasaki, 1954); Isshiki made a series of studies on volcanoes in the seven Izu islands (see Isshiki, 1963); and Aramaki did a detailed study on Asama volcano (see Aramaki, 1963). This group, headed by Kuno, established a distinguished school of petrology and volcanology in Japan at that time.

Petrologic studies on volcanic rocks also were carried out at Tohoku University, where S. Kozu had established a school of igneous petrology. Y. Kawano extended Kozu's school to investigate more extensively the chemical compositions of island arc igneous rocks (for example, see Kawano and others, 1961). These studies were advanced further by $\mathrm{K}$. Aoki, who initiated his studies on volcanic rocks of Iki Island, northwest of Kyushu (Aoki, 1959). Aoki and his colleagues made many analytical studies of volcanic rocks in northeastern Japan, and they contributed much to the understanding of the petrochemical characteristics of volcanic rocks and their lateril variations in Japanese island arcs (see Ishikawa and others, 1980. Fujimaki and Kurasawa, 1980). Aoki also investigated, partly with H. Kuno, upper mantle and lower crustal xenoliths, and he clarified the petrologic properties of the upper mantle and lower crust beneath Japanese island arcs (Aoki, 1971). Other notable petrochemical stud ies were performed at Hokkaido University. Y. Katsui, who was a student of T. Ishikawa and was influenced by K. Yagi, carried ont studies with his colleagues on many Quaternary volcanoes, maini on Hokkaido. They demonstrated that the lateral variations across the arc in Hokkaido are essentially the same as those in the northeast of Honshu and that calc-alkalic andesites and associated basalts show similar lateral variations across the are (Katsui, 1961; Katsui and others, 1978).

\section{Views from geophysical characteristics and evolution of island ares}

Important studies on the origin of island arc volcanic rocks wert made from other points of view. A. Sugimura investigated volcanos and volcanic rocks in relation to geophysical and tectonic character. istics of island arcs. Sugimura pointed out that the "volcanic front." which is a boundary between volcanic and nonvolcanic zones, can bc defined sharply in Japanese island arcs and that the volume ot Quaternary volcanic rocks decreases drastically from the volcanic front toward the backarc side (Sugimura, 1960; Sugimura and other 1963). This evidence puts an important constraint on the mechanism of generation of magmas in island arcs. He also showed relationship between geophysical features and the nature of volcanic rocks. These areas of Sugimura's work were extended by K. Nakamura who. taking into account plate tectonic theory, vigorously investigated the relationships between tectonism and the origin of volcanoes in island arcs (see Nakamura and Uyeda, 1980). His work was more volcanological than Sugimura's, but it also had an influence on the petrology of volcanic rocks.

Another important study of wider scope on arc volcanic roch. was made by A. Miyashiro, who was among S. Tsuboi's students and who made many significant contributions to metamorphic petrology. He examined the chemical compositions of volcanic rocks in island arcs and in active continental margins, clarified the chemical nature of island arc volcanic rocks, and distinguished compositional trends of tholeiitic and calc-alkalic series as fractional crystallization advanced. He pointed out that the proportion of calc-alkalic rock : increases as the continental-type crust develops beneath the volcanic arc (Miyashiro, 1974), which is important for understanding the genesis of calc-alkalic magmas and the evolution of island arc crust On the basis of his studies on island arc volcanic rocks, he suggested that the Troodos ophiolitic complex on Cyprus probably was forme in an island arc (Miyashiro. 1973). This greatly influenced later studies on ophiolites in the world.

\section{Experimental studies}

The experimental work on igneous petrology that had been pioneere, by S. Kozu and his colleagues at Tohoku University was not con:pletely terminated. K. Yagi, who was a student of Kozu and collat:orated with J.F. Schairer in 1-atmospheric experiments at the Gecphysical Laboratory, continued his experiments at Tohoku Universit: and applied the results to the crystallization of alkalic magmas ( $\mathrm{Yag}$. 1966). He also conducted many field and petrological studies on volcanic rocks. Yagi's experimental work was continued by $\mathbf{K}$. Onuma, who made 1 -atmospheric experiments on synthetic system. 
that are related mainly to the crystallization of silica-undersaturated magmas (Onuma and Yagi, 1967).

Experimental work related to the genesis of basalt magma at high pressures progressed greatly in the 1960 s after publication of the work by Yoder and Tilley (1962). I. Kushiro, a student of H. Kuno, was stimulated by Kuno's work, and he started high-pressure experiments at the Geophysical Laboratory, partly in cooperation with H.S. Yoder. He conducted experimental studies on the effects of pressure and water on the composition of magmas formed in the upper mantle. He confirmed Kuno's hypothesis that alkali basalt magma is formed at higher pressures than tholeiitic basalt magma by partial melting of the upper mantle peridotite (Kushiro, 1968). In addition, he found that the magmas formed under hydrous conditions are more enriched in silica than those formed under anhydrous conditions in the same pressure range (Kushiro, 1972). The results of this work were applied to the genesis of magmas in subduction zones. Later, Kushiro conducted measurements of physical properties of magmas at high pressures both at the Geophysical Laboratory and at the University of Tokyo. T. Fujii, who was one of the last students of $\mathrm{H}$. Kuno, developed a method of measuring the density of magma at high pressures (Fujii and Kushiro, 1977) and applied it to measuring the densities of melts of natural basalt compositions at pressures to $2 \mathrm{GPa}$.

\section{Geochemical studies}

Geochemical studies carried out by geochemists on volcanic rocks had significant influence on igneous petrology in Japan. Such geochemical studies were initiated by Y. Shibata and K. Kimura, who analyzed rocks of Asama and Oshima volcanoes (Kimura and Ito, 1936). Geochemists also collaborated with petrologists in studying volcanic rocks. For example, K. Sugawara and S. Oana collaborated with $\mathrm{S}$. Tsuboi in analyzing magmatic water trapped in nepheline basanite in Hamada, southwestern Japan. Later, K. Nagashima collaborated with $\mathrm{H}$. Kuno in analyzing pyroxene and volcanic rocks from Hakone in southeastern Honshu and from Hawaii (Kuno and Nagashima, 1952; Kuno and others, 1957). I. Iwasaki and T. Katsura did many analytical studies on volcanic rocks in Oshima and other volcanoes, partly in cooperation with petrologists; Katsura collaborated with G.A. Macdonald in the study of Hawaiian lavas and made a well-known contribution to the chemical compositions of basalts (Macdonald and Katsura, 1964). Notable geochemical studies by A. Masuda and Y. Matsui investigated rare-earth elements in volcanic rocks and discussed their origin from a global point of view (see Masuda and Matsui, 1966; Masuda, 1968). Their concept and discussion were unique and greatly stimulated petrologists. A fundamental study was made by Onuma and others (1968) on the partitioning of elements between phenocrysts and groundmass in volcanic rocks of the Japanese islands. They beautifully demonstrated sitecontrolled partition coefficients of elements that have a different ionic radius and charges. This study enabled us to predict the behavior of elements during fractional crystallization of magmas. The origin of igneous rocks in the Japanese islands was investigated also by means of isotopic systematics. For example, Tatsumoto (1969) determined the isotopic composition of lead $(\mathrm{Pb})$ in basalts in the Japanese island arcs and demonstrated that their ${ }^{238} \mathrm{U} /{ }^{204} \mathrm{~Pb}$ and ${ }^{23} \mathrm{Th} /{ }^{204} \mathrm{~Pb}$ ratios increase from the volcanic front toward the Sea of Japan side. On the basis of these results, he suggested that the subducting oceanic lithosphere is involved in the formation of arc magmas. Strontium (Sr) isotope studies related to the genesis of volcanic rocks also were made by several groups (for example, Hedge and Knight, 1969; Kaneoka and others, 1978; Kurasawa, 1979). These studies put constraints on the origin of magmas, such as the contribution of crustal materials to arc magmas and the source of arc magmas.

\section{Recent studies on the origin of arc magmas}

Studies made during approximately the last 10 years in Japan on the origin of arc magmas have focused primarily on quantitative estimates of the conditions of formation and on the source of the magmas in the subduction zones. Much effort also has been made in order to solve problems such as the origin of calc-alkalic andesite, the formation of a sharp volcanic front, and across-the-arc lateral variations in chemical composition of arc magmas and in the amount of magmas erupted.

\section{Genesis of arc basalt magmas}

As mentioned above, Kuno $(1959,1960)$ proposed a model of the basalt magmas formed along the Wadati-Benioff zone: tholeiitic magma is formed at $100-150 \mathrm{~km}$ depth; high-alumina basalt magma, at $150-200 \mathrm{~km}$ depth; and alkali basalt magma, at depths greater than $200 \mathrm{~km}$ by partial melting of peridotitic upper mantle. Later experimental studies (Green and Ringwood, 1967; Kushiro, 1968), however, indicate that such depth ranges are too deep for the generation of these magmas. More recently, Takahashi and Kushiro (1983) determined compositions of magmas formed by partial melting of an upper mantle peridotite at pressures up to $35 \mathrm{kbar}$ by using the "peridotite capsule" technique. Their results show that quartz tholeiitic magma is formed at pressures below $8 \mathrm{kbar}$; olivine tholeiitic magma, from 8 to $15 \mathrm{kbar}$; and alkali basalt magma, at pressures greater than 15 kbar under anhydrous conditions. Tatsumi and others (1983) determined more specifically the depth ranges for the generation of arc basalt magmas in the northeastern Japan arc. They first estimated the chemical compositions of primary basalt magmas on the basis of the least fractionated basalts in the northeastern Japan arc, and then they determined the conditions of equilibration of these primary basalt magmas with upper mantle peridotites. The conditions of equilibration under anhydrous conditions are as follows: 11 kbar $(35 \mathrm{~km}), 1,330^{\circ} \mathrm{C}$ for primary tholeiitic magma; $15 \mathrm{kbar}(45$ $\mathrm{km}), 1,340{ }^{\circ} \mathrm{C}$ for high-alumina basalt magma; and $17 \mathrm{kbar}(50 \mathrm{~km})$, $1,360{ }^{\circ} \mathrm{C}$ for primary alkali olivine basalt magma. In the presence of $1-3$ weight percent water, the pressures given above increase by $2-6$ kbar and the temperatures decrease by $20-40{ }^{\circ} \mathrm{C}$. Because these estimates are based on minimum assumptions and reasonable boundary conditions, they may not change greatly (that is, pressures by 5 kbar and temperatures by $50{ }^{\circ} \mathrm{C}$ ). The temperatures of equilibration for these primary magmas $\left(1,300^{\circ} \mathrm{C}\right)$ are significantly higher than the temperatures estimated at such depths from the equilibration temperatures of the upper mantle xenoliths. To solve this problem, Sakuyama (1983), Tatsumi and others (1983), and Kushiro (1983) suggested that primary arc basalt magmas are formed in hot diapirs that ascend from a deeper, hot source region within the mantle wedge. If we assume the adiabatic ascent of the diapirs, the temperature of the source region is estimated to be about $1,400{ }^{\circ} \mathrm{C}$ at a depth of $100 \mathrm{~km}$ beneath the volcanic front of the northeastern Japan arc. They interpreted the depth of equilibration to be that of the segregation of magmas from diapirs; the depth of segregation increases from the volcanic front toward the Sea of Japan side, which may be due to a decrease of temperature or to an increase of viscosity of the uppermost mantle beneath the Japanese islands. They also suggested that the degree of partial melting within the diapirs decreases from the volcanic front toward the Sea of Japan side. This is consistent with an across-the-arc lateral variation in chemical composition (for example, alkali composition) of volcanic rocks. 


\section{Origin of calc-alkalic andesite}

The origin of calc-alkalic andesite has been a matter of much debate. Gill (1981) presented a thorough review of the hypothesis on the origin of calc-alkalic andesite. Following is a very brief review of the studies made on this problem in Japan. Kuno (1950) argued that calc-alkalic (hypersthenic rock series) andesite is formed by the assimilation of granitic materials by tholeiitic (pigeonitic rock series) basalt magma. Later, he accepted fractionation of basaltic magma under high oxygen fugacities, which was postulated by Osborn (1959) as a major mechanism for the formation of calc-alkalic andesite magma (Kuno, 1968). This mechanism has been accepted widely (Gill, 1981). However, the parental magma of calc-alkalic andesite, which must be lower in temperature and must contain more water than tholeiitic magma (Ishii, 1975, 1980), has not been defined clearly. A different possibility was suggested by Sakuyama (1979), who found evidence of the mixing of basaltic and dacitic magmas in the formation of calc-alkalic andesite in many volcanoes in central Japan, and he suggested that this mechanism may be important for the formation of calc-alkalic andesite in general. However, the mechanism of formation of dacitic magma was not solved. Another possible mechanism is that calc-alkalic andesite magma is formed by partial melting of hydrous upper mantle peridotite. Tatsumi (1981) carried out melting experiments on magnesian andesites in the Setouchi province and showed that they can be formed by direct partial melting of hydrous upper mantle peridotite at depths of $40-50 \mathrm{~km}$. Boninite, which is a type of magnesian andesite, also was shown to be a product of direct partial melting of upper mantle peridotite at depths of 20-30 km (Umino, 1988; Umino and Kushiro, 1990). A completely different possibility was suggested by Takahashi (1986a), who proposed that calc-alkalic andesite magma is formed by partial melting of the lower crust and that this is triggered by the injection of basalt magma. Other hypotheses have been presented as well on the origin of calc-alkalic andesite (for example, see Ringwood, 1974). At the present, it is not certain which of these hypotheses is the correct one. The situation also exists that most of these possibilities are correct and that calc-alkalic andesite is formed by several different mechanisms. We have to admit that the origin of calc-alkalic andesite is still not well understood, in contrast to the origin of arc basalt magmas.

\section{Mantle wedge and subducted slab}

Another important study that is relevant to the generation of magmas is a study of the velocity structure and the three-dimensional $Q_{\text {s }}$ (seismic anelasticity) structure of the mantle wedge in the northeastern Japan arc (Umino and Hasegawa, 1984; Hasegawa and others, 1991). This study demonstrated that the subducted slab has an extremely high $Q_{s}$ value $(1,500)$, whereas the mantle wedge between the volcanic front and the coast of the Sea of Japan has very low $Q$ values $(100)$. Most likely, the region that has such low $Q_{s}$ values is partially melted, or the temperature is below, but very close to, the solidus temperature (Sato and others, 1989; Sacks and others, 1989). On the basis of the temperature of primary olivine tholeitic magma (Tatsumi and others, 1983), the temperature of this region is estimated to be close to $1,400{ }^{\circ} \mathrm{C}$ beneath the volcanic front in northeastern Japan. In the presence of water, this region must be partially melted, and the amount of melt formed in this region depends on the amount of water supplied. The bulk density of this region is lower than that of the overlying mantle wedge, even under anhydrous conditions (Kushiro, 1987). The materials in this region, therefore, would tend to ascend, probably as diapirs. Hasegawa and others (1985) also demonstrated that the low-velocity region extends upward to the roots of volcanoes, a finding that supports the uprising of hot materials. On the other hand, most parts of the subducted slab, which has high velocities and high $Q_{s}$ values, may not be melted beneath the northeastern Japan arc, but it would most probably be the source of water for the arc magmas. Tatsumi (1986) determined the conditions of the breakdown of amphibole and phlogopite at high pressures and showed that amphibole in the subducted slab breahs down just beneath the volcanic front and that phlogopite breaks dow $\mathrm{r}$ at greater depths or on the backarc side in the northeastern Japan ar. Water released from the subducted slab must be a supercritical fluid that dissolves significant amounts of silica, alkalis, and other contponents. Such fluids may trigger partial melting of the overlying peridotite.

Experimental studies at very high pressures, which were pioneered and developed by S. Akimoto, N. Kawai, and M. Kumazawa. have contributed greatly to understanding the phase relationships if the upper mantle materials, including those in subduction zone-. Yamamoto and Akimoto (1977) found new hydrous magnesiumi silicate minerals at pressures greater than $5 \mathrm{GPa}$. These minerals at: formed by the breakdown of serpentine and may play a role in the subduction process; they may carry water down to depths even greater than $200 \mathrm{~km}$, where they break down to release water. Otht: important experiments at very high pressures are those on the melting of the upper mantle peridotite at pressures as great as $14 \mathrm{GF}$ i (Takahashi, 1986b). The results indicate that the melt formed becomes komatiitic and even peridotitic at pressures greater than 1 ; $\mathrm{GPa}$. These studies are important for the genesis of source materials of magmas, including those in the mantle wedge of the subduction zones.

\section{Some recent geochemical studies on genesis of arc magmas}

Newer geochemical studies have contributed also to our understand. ing the genesis of magmas in Japanese island arcs. A few notabl: examples are given below. $N$. Onuma and his colleagues made a series of studies on the $\mathrm{Sr} / \mathrm{Ca}-\mathrm{Ba} / \mathrm{Ca}$ systematics of volcanic rock: (Onuma and others, 1981, 1983). By using these ratios in volcanic rocks, they estimated the degree of partial melting required to pro duce parental magmas, as well as the degree of fractionation of magmas needed to produce volcanic rocks in the Izu islands and in many other volcanoes in the Japanese islands. Although their abso lute values may need further examination, at least their relative values are quite useful for understanding the genesis of these volcanic rocks. Isotopic studies of volcanic rocks are also important for understanding their genesis. Studies by Notsu (1983) of Sr isotope: in volcanic rocks are notable; he demonstrated that ${ }^{87} \mathrm{Sr}{ }^{86} \mathrm{Sr}$ ratios in basalt and andesite decrease going from the volcanic front toward the Sea of Japan across the northeastern Japan arc and that an anomalously high value exists in the southern part of the arc. Other impor tant isotopic studies are of neodymium isotopes of volcanic rocks. studies carried out by Nohda and his colleagues (Nohda and Was serburg, 1981; Nohda and others, 1988) and by Nakamura and his colleagues (Nakamura and others, 1990). This work suggests that the source of are magmas is heterogeneous, at least in isotopic compositions, and it suggests that complex processes, such as interaction with the subducting slab, have occurred in the mantle wedge beneath the Japanese island arcs.

Of course, many other studies have been conducted on the genesis of magmas and volcanic rocks in the Japanese island arcs. In particular, the work being carried out by young petrologists. geochemists, and geophysicists is stimulating and will change a great deal of our understanding of arc magmas. I am sure that a review written after several more years have passed will have significant additions to the review presented here. 


\section{References}

Aoki. K., 1959, Petrology of alkali rocks of the Iki Islands and Higashimatuura district, Japan: Science Reports of the Tohoku University, series 3, v. 6, p. 261-310.

-1971, Petrology of mafic inclusions from Itinome-gata, Japan: Contributions to Mineralogy and Petrology, v. 30, p. 314-331.

Aramaki, S., 1963, Geology of Asama volcano: Journal of the Faculty of Science, University of Tokyo, section 2, v. 14, p. 229-443.

Fujii, T., and Kushiro, I., 1977, Density, viscosity, and compressibility of basaltic liquid at high pressures: Carnegie Institution of Washington Yearbook 76, p. 419-424.

Fujimaki, H., and Kurasawa. H., 1980, Lateral variation of REE pattern of basaltic magma across the Japan arc: Journal of the Japanese Association of Mineralogists, Petrologists and Economic Geologists, v. 75, p. $313-322$.

Gill, J., 1981, Orogenic andesites and plate tectonics: Berlin, SpringerVerlag, $390 \mathrm{p}$

Green, D.H., and Ringwood, A.E., 1967, The genesis of basaltic magmas: Contributions to Mineralogy and Petrology, v. 15, p. 103-190.

Hasegawa, A.. Zhao, D., Yamamoto, A., and Horiuchi, S., 1991, Deep structure of volcanoes and its relation to the occurrence of crustal earthquakes in the northeastern Japan arc as inferred from seismic observations: Bulletin of the Volcanological Society of Japan, v. 36, p. 197-210. [In Japanese.]

Hedge, C.E., and Knight, R.J., 1969, Lead and strontium isotopes in volcanic rocks from northeastern Honshu, Japan: Geochemical Journal, v. 3, p. 15-24.

tshii, T., 1975, The relations between temperature and composition of pigeonite in some lavas and their application in geothermometry: Mineralogical Journal, v. 8 , p. 48-57.

1980. Pyroxene geothermometry of basalts and an andesite from the Palau-Kyushu and West Mariana ridges, Deep Sea Drilling Project Leg 59, in Kroenke, L., Scott, R.B., and others, Initial reports of the Deep Sea Drilling Project, v, 59: Washington, D.C., U.S. Government Printing Office, p. 693-718.

ishikawa, K., Kanisawa, S. and Aoki, K., 1980, Content and behavior of fluorine in Japanese Quaternary volcanic rocks and petrogenetic application: Journal of Volcanology and Geothermal Research, v. 8, p. $161-175$.

Isshiki, N., 1963, Petrologv of Hachijou-jima volcano group, seven Izu islands, Japan: Journal of the Faculty of Science, University of Tokyo, section 2 , v. 15 , p. 91-134

Kaneoka, I., Matsuda, J., Zashu, J., Takahashi, E., and Aoki, K., 1978, $\mathrm{Ar}$ and $\mathrm{Sr}$ isotopes of mantle-derived rocks from the Japanese islands: Bulletin Volcanologique v. 41, p. 424-433.

Kani, K., 1934, The measurement of the viscosity of basalt glass at high temperatures, 1 and 2: Proceedings of the Japan Academy, v. 10, p. $29-32,79-82$.

Katsui. Y., 1961, Petrochemistry of the Quaternary volcanic rocks of Hokkaido and surrounding areas: Joumal of the Faculty of Science, Hokkaido University, series 4, v. 11, p. 1-58.

Katsui, Y., Oba, Y., Ando, S., Nishimura, S., Masuda, Y., Kurasawa, H., and Fujimaki, H., 1978, Petrochemistry of the Quaternary volcanic rocks of Hokkaido, north Japan: Journal of the Faculty of Science, Hokkaido University, series 4, v. 18, p. 449-484.

Kawano, Y., Yagi, K., and Aoki, K., 1961, Petrography and petrochemistry of volcanic rocks of Quaternary volcanoes of northeast Japan: Science Reports of the Tohoku University. series 3, v. 7 . p. $1-46$.

Kennedy, W.Q., 1933. Trends of differentiation in basaltic magnas: American Journal of Science, 5th series, v. 25, p. 31-47.

Kennedy, W.Q., and Anderson, E.M., 1938, Crustal layers and the origin of magmas: Bulletin Volcanologique, series 2, v. 3, p. 23-82.

Kimura, K., and Ito, H., 1936, Trace elements of the lavas of Asama volcano: Journal of the Japanese Association of Mineralogists, Petrologists and Economic Geologists, v. 16, p. 79-80. [In Japanese.]

Koto, B., 1884, Studies on some Japanese rocks: Quarterly Journal of the Geological Society of London, v. 40 , p. $431-457$.

1916, On the volcanoes of Japan, I, II, III, IV and V: Journal of the Geological Society of Tokyo, v. 23, p. 1-13, 17-28, 29-56, $77-94,95-127$.
Kozu, S., and Kani, K., 1935, Viscosity measurements of the ternary system diopside-albite-anorthite at high temperatures: Proceedings of the Imperial Academy of Tokyo, v. 11, p. 383-385.

Kuno, H., 1950, Petrology of Hakone volcano and adjacent areas, Japan: Geological Society of America Bulletin, v. 61, p. 957-1020.

1959, Origin of Cenozoic petrographic provinces of Japan and surrounding areas: Bulletin Volcanologique, v. 20, p. 37-76.

1960, High-alumina basalt: Journal of Petrology, v. 1, p. 121-145.

1967. Mafic and ultramafic nodules for Ichinomegata, Japan, in Wyllie, P.J., ed., Ultramafic and related rocks: New York, John Wiley, p. 337-342.

-1968 , Origin of andesite and its bearing on the island arc structure: Bulletin Volcanologique, v. 32, p. 141-176.

Kuno, H., and Aoki, K., 1970, Chemistry of ultramafic nodules and their bearing on the origin of basaltic magmas: Physics of the Earth and Planetary Interiors, v. 3, p. 273-301.

Kuno, H., and Nagashima, K., 1952, Chemical compositions of hypersthene and pigeonite in equilibrium in magma: American Mineralogist, v. 37 , p. $1000-1006$.

Kuno, H., Yamasaki, K., Iida, C., and Nagashima, K., 1957, Differentiation of Hawaiian magmas: Japanese Journal of Geology and Geography, v. 28, p. 179-218.

Kurasawa, H., 1979, Isotopic composition of strontium in volcanic rocks from Fuji, Hakone and Izu area, central Japan: Bulletin of the Volcanological Society of Japan, v. 24, p. 135-152.

Kushiro, I., 1968, Compositions of magmas formed by partial melting of the earth's upper mantle: Journal of Geophysical Research, v. 73, p. 619-634.

1972, Effect of water on the composition of magmas formed at high pressure: Journal of Petrology, v. 13, p. 311-334.

1983, On the lateral variations in chemical compositions and volume of Quaternary volcanic rocks across Japanese arcs: Journal of Volcanology and Geothermal Research, v. 18, p. 435-447

1987, A petrological model of the mantle wedge and lower crust in the Japanese island arcs, in Mysen, B.O., ed., Magmatic processes: Physicochemical principles: Geochemical Society Special Publication, no. 1, p. 165-181.

Macdonald, G.A., and Katsura, T., 1964, Chemical composition of Hawaiian lavas: Journal of Petrology, v. 5, p. 82-133.

Masuda, A., 1968, Geochemistry of lanthanides in basalts of central Japan: Earth and Planetary Science Letters, v. 4, p. 284-292.

Masuda, A., and Matsui, Y., 1966, The difference in lanthanide abundance pattern between the crust and the chondrite and its possible meaning to the genesis of crust and mantle: Geochimica et Cosmochimica Acta, v. 30 , p. $239-250$.

Miyashiro, A., 1973, The Troodos ophiolitic complex was probably formed in an island arc: Earth and Planetary Science Letters, v. 19, p. $218-224$.

1974, Volcanic rock series in island ares and continental margins: American Journal of Science, v. 274, p. 321-355.

Nakamura, E., McCulloch, M.T., and Campbell, I.H., 1990, Chemical geodynamics in the back-arc region of Japan based on the trace element and $\mathrm{Sr}-\mathrm{Nd}$ isotopic compositions: Tectonophysics, v. 174, p. 207-233.

Nakamura, K., and Uyeda, S., 1980, Stress gradient in arc-back-are regions and plate subduction: Journal of Geophysical Research, v. 85, p. $6419-6428$.

Nohda, S., Tatsumi, Y., Otofuji, Y., Matsuda, T.. and Ishizaka, K., 1988, Asthenospheric injection and back-are opening: Isotopic evidence from northeast Japan: Chemical Geology, v. 68, p. 317-327.

Nohda, S., and Wasserburg. G.J., 1981. Nd and Sr isotopic study of volcanic rocks from Japan: Earth and Planetary Science Letters, v. 52, p. 264-276.

Notsu, K., 1983. Strontium isotope composition in volcanic rocks from the northeast Japan arc: Journal of Volcanology and Geothermal Research, v. 18 , p. $531-548$

Onuma, K., and Yagi, K., 1967, The system diopside-akermanitenepheline: American Mineralogist, v. 52, p. 227-243.

Onuma, N., Higuchi, H., Wakita, H., and Nagasawa, H., 1968, Trace element partition between two pyroxenes and the host lava: Earth and Planetary Science Letters, v. 5, p. 47-51. 
Onuma, N., Hirano, M., and Isshiki, N., 1981, Sr/Ca-Ba/Ca systematics in four volcanoes of Oshima, Izu Islands, Japan: Geochemical Journal, v. 15 . p. $315-324$.

1983, Genesis of basalt magmas and their derivatives under the Izu Islands, Japan, inferred from $\mathrm{Sr} / \mathrm{Ca}-\mathrm{Ba} / \mathrm{Ca}$ systematics: Journal of Volcanology and Geothermal Research, v. 18, p. 511-529.

Osborn, E.F., 1959, Role of oxygen pressure in the crystallization and differentiation of basaltic magma: American Journal of Science, v. 257, p. 609-647.

Ringwood, A.E, 1974, The petrological evolution of island arc systems: Journal of the Geological Society of London, v. 130, p. 183-204.

Sacks, I., Sato, H., and Morris, J., 1989, Magma generation in subduction zones, in Hart, S.R., and Gulen, L., eds., Crust/mantle recycling at convergence zones: London, Kluwer Academic Publishers, p. 139-144.

Sakuyama, M., 1979, Evidence of magma mixing: Petrological study of Shirouma-Oike calc-alkaline andesite volcano, Japan: Journal of Volcanology and Geothermal Research, v. 5, p. 179-208.

1983, Petrology of arc volcanic rocks and their origin by mantle diapir: Journal of Volcanology and Geothermal Research, v. 18, p. $297-320$.

Sato, H., Sacks, I.S., Murase, T., Muncill, G.E., and Fukuyama, H., $1989, \mathrm{Q}_{\mathrm{p}}$-melting temperature relation in peridotite at high pressure and temperature; attenuation mechanism and implications for the mechanical properties of the upper mantle: Journal of Geophysical Research, v. 94. p. 10647-10661.

Sugi, K., 1938, On sanukitic rocks in the vicinity of Takamatsu, Shikoku, with special reference to xenocrysts contained in them: Bulletin of the Volcanological Society of Japan, v. 4, p. 17-33. [In Japanese.]

1942, Petrological studies on the basaltic rocks from Sanin and northern Kyushu, southwestern Japan: Memoirs of Faculty of Science, Kyushu Imperial University, series D, v. 1, p. 69-90.

Sugimura, A., 1960, Zonal arrangements of some geophysical and petrological features in Japan and its environs: Journal of the Faculty of Science, University of Tokyo, section 2, v. 12, p. 133-153.

Sugimura, A., Matsuda, T., Chinzei, K., and Nakamura, K., 1963. Quantitative distribution of late Cenozoic volcanic materials in Japan: Bulletin Volcanologique, series 2, v. 26, p. 125-140.

Takahashi, E., 1986a, Genesis of calc-alkali andesite magma in a hydrous mantle-crust boundary: Petrology of lherzolite xenoliths from the Ichinomegata crater, Oga peninsula, northeast Japan, II: Journal of Volcanology and Geothermal Research, v. 29, p. 355-395.

Takahashi, E., 1986b, Melting of a dry peridotite KLB-1 up to $14 \mathrm{GPa}$; Implications on the origin of peridotite upper mantle: Journal of Geophysical Research, v. 91, p. 9367-9382.

Takahashi, E., and Kushiro, I., 1983, Melting of dry peridotite at high pressures and basalt magma genesis: American Mineralogist, v. 68, p. 859-879.

Tatsumi, Y., 1981, Melting experiments on a high magnesian andesite: Earth and Planetary Science Letters, v. 54, p. 356-365.

1986, Formation of the volcanic front in subduction zones: Geophysical Research Letters, v. 13, p. 717-720.

Tatsumi, Y., Sakuyama, M., Fukuyama, H., and Kushiro, I., 1983, Generation of arc basalt magmas and thermal structure of the mantle wedge in subduction zones: Journal of Geophysical Research, v. 88, p. $5815-5825$.

Tatsumoto, M., 1969, Lead isotopes in volcanic rocks and possible oceanfloor thrusting beneath island arcs: Earth and Planetary Science Letters, v. 6 , p. $369-376$.
Tilley, C.T., 1950, Some aspects of magmatic evolution: Quarterly Journal of the Geological Society of London, v. 106, p. 37-61.

Tomita, T., 1935, On the chemical compositions of the Cenozoic alkaline suite of the Circum-Japan sea region: Journal of the Shanghai Science Institute, section 2, v. 1, p. 227-306.

Tsuboi, S., 1923, A dispersion method of determining plagioclase in cleavage-flakes: Mineralogical Magazine, v. 20, p. 108-122. 1932 , On the course of crystallization of pyroxenes from rockmagmas: Japanese Journal of Geology and Geography, v. 10 , p. 6782.

Tsuya, H., 1937, On the volcanism of the Huzi volcanic zone, with special reference to the geology and petrology of Idu and Southern Islands: Bulletin of the Earthquake Research Institute, University of Tokyo, v. 15 , p. $215-357$.

1940, Geological and petrological studies of Huzi volcano (III): Bulletin of the Earthquake Research Institute, University of Tokyo, v. 18 , p. 419-445. [In Japanese.]

Umino, N., and Hasegawa, A., 1984, Three-dimensional Qs structure in the northeastern Japan Arc: Zisin, v. 37, p. 217-228.

Umino, S., 1988, Geological and petrological study of boninites and related rocks from Chichijima, Bonin Islands: Tokyo, University of Tokyo, $\mathrm{Ph}$.D. thesis, $367 \mathrm{p}$.

Umino, S., and Kushiro, I., 1990, Experimental studies on boninite petrogenesis, in Crawford, A.J., ed., Boninites and related rocks: London, Unwin Hyman, p. 89-111.

Yagi, K., 1966, The system acmite-diopside and its bearing on the stability relations of natural pyroxenes of the acmite-hedenbergite-diopside series: American Mineralogist, v. 51, p. 976-1000.

Yamamoto, K., and Akimoto, S., 1977, The system $\mathrm{Mg0}-\mathrm{SiO}_{2}-\mathrm{H}_{2} \mathrm{O}$ at high pressures and temperatures-Stability field for hydroxyl-chondrodite, hydroxyl-clinohumite and 10A-phase: American Journal of Science, v. 277, p. 288-312.

Yamasaki, M., 1954, On the chemical composition of lavas of NyohoAkanagi volcano, Nikko: Journal of the Faculty of Science, University . of Tokyo, section 2, v. 9, p. 345-354.

Yoder, H.S., and Tilley, C.E., 1962, Origin of basalt magmas: An experimental study of natural and synthetic rock systems: Journal of Petrology, v. 3, p. 342-532.

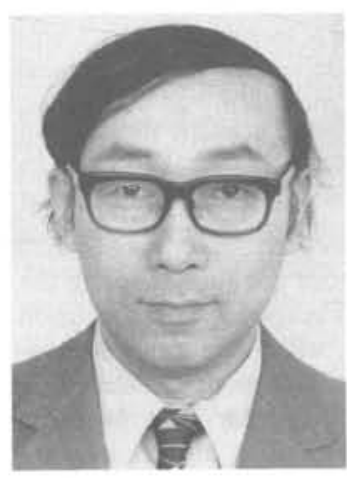

Dr. Ikuo Kushiro is a Professor of Petrology at the Geological Institute, University of Tokyo. He received his doctorate from the University of Tokyo in 1962. Since then he had been conducting experimental studies on the problems of magma genesis, upper mantle petrology, and condensation of gas in the primitive solar nebula, both at the University of Tokyo and at the Geophysical Laboratory of the Carnegie Institution of Washington, D.C., USA. He is now serving as Chairman of the Scientific Program Committee of the 29th International Geological Congress in Kyoto. 